\title{
ХАРАКТЕРИСТИКА ВИЖИВАННЯ НОВОНАРОДЖЕНИХ ІЗ НИЗЬКОЮ МАСОЮ ТІЛА ПРИ НАРОДЖЕННІ
}

\author{
${ }^{1}$ ДУ «Український інститут стратегічних досліджень Міністерства охорони здоров'я України», \\ м. Київ, Україна \\ ${ }^{2}$ Національна медична академія післядипломної освіти імені П.Л. Шупика, м. Київ, Україна
}

\begin{abstract}
Мета: вивчити та проаналізувати показники виживання новонароджених із низькою масою тіла при народженні в умовах впровадження регіоналізації перинатальної допомоги в Україні.

Матеріали і методи. У ході виконання дослідження використано статистичний та бібліосемантичний методи. Матеріалами дослідження стали дані Держкомстату України та перинатального аудиту за 2011-2015 роки.

Результати. Показники виживання новонароджених з дуже малою масою тіла у перші 168 годин життя склали 81,3\%-81,9\%, у т. ч. 3 масою тіла при народженні 500-999 г -64,2\%-63,0\%, 3 масою тіла при народженні 1000-1499 г 90,1\%-91,3\%. Встановлена позитивна тенденція щодо перинатальної смертності - 8,6 на 1000 народжених живими і мертвими у 2014 р. і 8,5 у 2015 р. та неонатальної - 3,4 і 3,1 на 1000 народжених живими відповідно.

Висновки. Показана ефективність впровадження регіоналізації перинатальної допомоги в країні.
\end{abstract}

КЛЮЧОВІ СЛОВА: новонароджені із низькою масою тіла при народженні, виживання, перинатальна допомога, регіоналізація.

Метою регіоналізаціії перинатальної допомоги визначено підвищення якості, доступності перинатальної допомоги з урахуванням: раціонального використання можливостей існуючої системи надання медичної допомоги жінкам репродуктивного віку, вагітним, роділлям, породіллям, новонародженим; створення можливості виходжування дітей з малою та дуже малою масою тіла при народженні, що сприятиме зниженню материнської, перинатальної і малюкової смертності та попередженню дитячої інвалідності [2-5].

Наразі в економічно розвинених країнах зниження перинатальної і малюкової смертності відбувається передусім за рахунок підвищення якості медичної допомоги дітям із дуже малою масою тіла при народженні. За даними ВООЗ, в економічно розвинених країнах виживання новонароджених у перші 168 годин життя 3 масою тіла при народженні 500-999 г становить 30,0\%, а новонароджених 3 масою тіла при народженні 1000-1499 г - 70\% [1]. Виживання дітей із дуже малою масою тіла при народженні в США, Японії і більшості країн Західної Європи досягло 80 і 95\% відповідно [6;7].

Мета роботи: вивчити та проаналізувати показники виживання новонароджених із низькою масою тіла при народженні в умовах впровадження регіоналізації перинатальної допомоги в Україні.

Матеріали і методи. У ході виконання дослідження використано статистичний та бібліосемантичний методи. Матеріалами дослідження стали

() О.О. Дудіна, Ю.Ю. Габорець, Г.А. Дзюба, 2016 дані Держкомстату України та перинатального аудиту за 2011-2015 роки.

Результати дослідження та їх обговорення. За даними перинатального аудиту за методикою BOO3 BABIES-MATRICA, виживання недоношених із надзвичайно малою масою тіла при народженні (500-999 г) за період впровадження регіоналізації перинатальної допомоги мало тенденцію до зростання з $57,58 \%$ у 2011 р. до $63,88 \%$, ВШ3 95\% ДІ 1,3 $(1,1-1,5)$ із тенденцією до зменшення у 2015 р. $(63,88 \%)$ (рис. 1).

При цьому виживання немовлят, народжених із масою тіла при народженні 1000-1499 г, зросло 3 87,34\% у 2011 р. до 90,41\% у 2015 р., ВШ з 95\% ДІ $1,4(1,4-1,6)$.

Доведено, що виживання новонароджених залежить як від маси тіла при народженні, так і від рівня кваліфікації медичних працівників та оснащення медичним обладнанням закладів перинатальної допомоги. Очікувано найнижчий рівень виживання новонароджених має бути в закладах перинатальної допомоги (ЗПД) первинного рівня, найвищий - у ЗПД III рівня. За даними моніторингу, в Україні виживання новонароджених у перші 168 годин життя 3 масою тіла при народженні 500999 г у 2014 р. коливалося від 50,9\% у ЗПД І рівня до 64,4\% у ЗПД II рівня, 63,6\% у ЗПД ІІІ рівня, у 2015 р. - відповідно 65,0\%, 69,7\% і 59,4\%. Як у 2014 р., так і в 2015 р., виживання новонароджених із масою тіла при народженні 500-999 г було найвищим у ЗПД II рівня (рис. 2). 


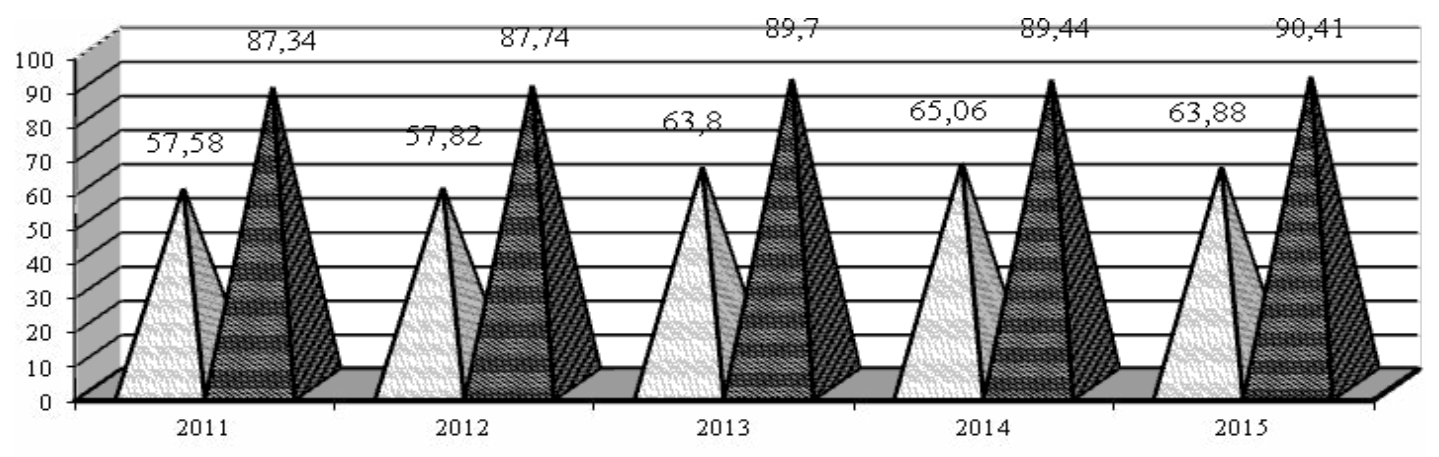

ฉ500-999 r $\mathbf{0} 1000-1499$ I

Puc.1. Виживання новонароджених із низькою масою тіла при народженні (менше 1500 г) після перших 168 годин життя у 2011-2015 рр.

(на 100 народжених живими)

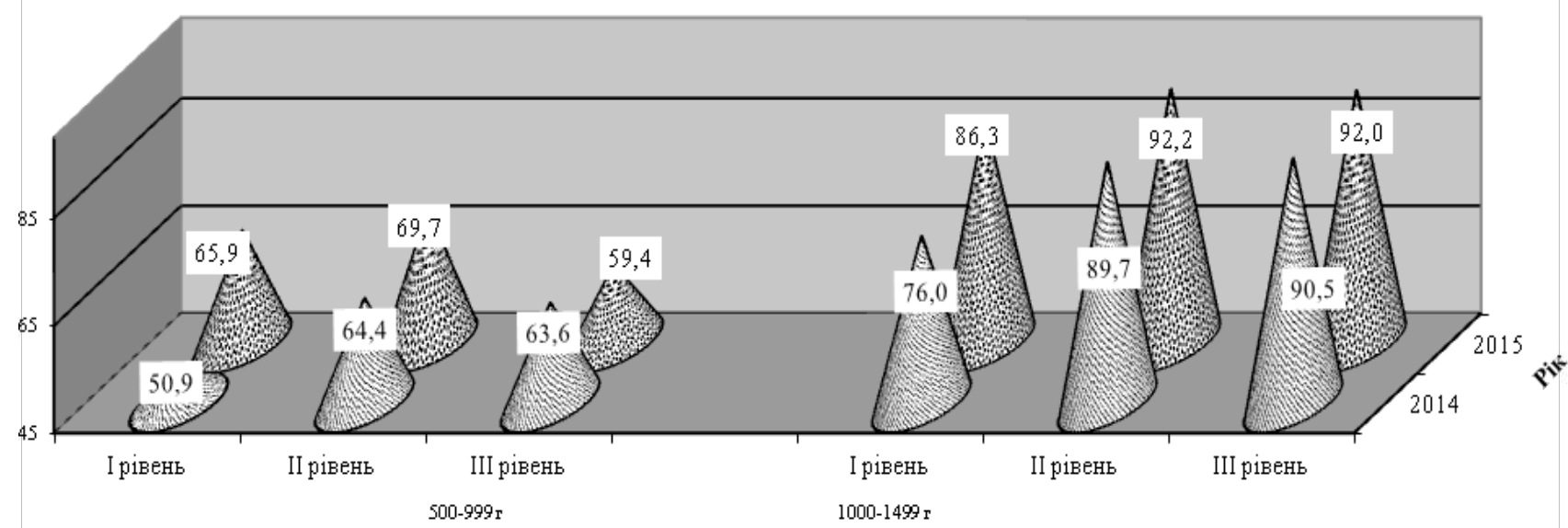

Рuc. 2. Залежність виживання новонароджених у перші 168 годин життя від маси тіла при народженні та рівнів 3Пд 2014, 2015 рр., \%

При цьому у 2015 р. виживання цієї категорії новонароджених у ЗПД ІІІ рівня було нижчим, ніж у ЗПД I та II рівнів. Виживання новонароджених із масою тіла при народженні 1000-1499 г у 2014 р. становило 76,0\% у ЗПД І рівня, 89,7\% у ЗПД II рівня і 90,5\% і у ЗПД III рівня, а у 2015 р. - 86,3\%, 92,2\%, 92,0\% відповідно. Потенційні проблеми 3 інтерпретацією отриманих результатів виживання новонароджених із дуже малою масою тіла при народженні у ЗПД I, II і III рівнів, вірогідно, можуть бути спричинені некоректністю даних реєстрації живонароджень із надзвичайно малою масою тіла при народженні у ЗПД I та II рівнів та недостатньою оснащеністю ЗПДІІ рівня лікувально-діагностичною апаратурою. Останнє підтверджується тим, що якщо в цілому у 2015 р. у ЗПД ІІІ рівня виживання новонароджених з масою тіла при народженні 500999 г становило 59,4\%, то у перинатальних центрах III рівня, створених за сприяння Національного проекту «Нове життя - нова якість охорони материнства і дитинства» і достатньо оснащених високотехнологічною лікувально-діагностичною апаратурою, - 66,7\%, ВШ 3 95\% ДІ 1,3 (1,0-1,6), а 3 масою тіла 1000-1499 г - 92,0\% і 93,3\%, Вш з 95\% ДІ 1,3 (0,9-1,9) відповідно.
У цілому показники виживання новонароджених із дуже малою масою тіла при народженні $€$ неоднорідними у часі і в розрізі регіонів. Як видно 3 таблиці, за даними МіО РПД у 2015 р. надзвичайно високий $(95,2 \%)$ показник виживання новонароджених із надзвичайно малою масою тіла при народженні зареєстровано у Миколаївській області, високі (більше 75\%) - у Волинській, Дніпропетровській, Житомирській, Закарпатській, Чернівецькій, а низькі (менше 40\%) - у Івано-Франківській, Кіровоградській, Сумській, Хмельницькій областях. Різниця показників виживання цієї вагової групи новонароджених порівняно з 2014 р. збільшилася у 1,3 разу. Значно менші географрічні розбіжності притаманні показникам виживання новонароджених із масою тіла при народженні 1000,0-1499,0 г від 95,9\% у м. Києві, 95,7\% у Кіровоградській області до 84\%-88\% у Чернівецькій, Черкаській, Рівненській, Львівській і Житомирській областях.

Тенденція до зниження виживання новонароджених 3 надзвичайно малою масою тіла при народженні у 2015 р. порівняно з 2014 р. зумовлена зниженням виживання їх в 7-ми регіонах Дніпропетровській, Запорізькій, Київській, Львівській, Сумській, Харківській і Херсонській облас- 
Таблиця. Характеристика виживання новонароджених з дуже низькою масою тіла при народженні, 2014-2015 рр., \%

\begin{tabular}{|c|c|c|c|c|}
\hline \multirow{2}{*}{$\begin{array}{c}\text { Адміністративно- } \\
\text { територіальна одиниця }\end{array}$} & \multicolumn{2}{|c|}{$\begin{array}{c}\text { Маса тіла при народженні } \\
\text { 500-999 г }\end{array}$} & \multicolumn{2}{|c|}{$\begin{array}{c}\text { Маса тіла при народженні } \\
\text { 1000-1499 г }\end{array}$} \\
\hline & $2014 p$. & 2015 p. & 2014 p. & 2015 p. \\
\hline Вінницька & 57,7 & 73,7 & 89,5 & 90,5 \\
\hline Волинська & 74,2 & 76,0 & 91,4 & 91,8 \\
\hline Дніпропетровська & 79,2 & 76,7 & 88,0 & 91,7 \\
\hline Житомирська & 71,8 & 83,9 & 82,8 & 87,3 \\
\hline Закарпатська & 67,6 & 77,8 & 92,2 & 92,6 \\
\hline Запорізька & 74,5 & 63,9 & 94,1 & 91,8 \\
\hline Івано-Франківська & 60,9 & 31,3 & 87,8 & 88,6 \\
\hline Київська & 59,5 & 73,5 & 83,8 & 93,6 \\
\hline Кіровоградська & 52,9 & 31,3 & 93,3 & 95,7 \\
\hline Львівська & 41,5 & 40,9 & 85,7 & 87,7 \\
\hline Миколаївська & 87,5 & 95,2 & 92,6 & 93,3 \\
\hline Одеська & 56,7 & 58,6 & 88,8 & 91,7 \\
\hline Полтавська & 69,0 & 69,0 & 90,8 & 90,8 \\
\hline Рівненська & 55,3 & 59,2 & 89,9 & 86,6 \\
\hline Сумська & 50,0 & 36,4 & 89,2 & 93,2 \\
\hline Тернопільська & 53,8 & 56,5 & 92,6 & 91,3 \\
\hline Харківська & 70,3 & 61,4 & 93,0 & 91,6 \\
\hline Херсонська & 80,0 & 46,4 & 90,5 & 91,3 \\
\hline Хмельницька & 37,9 & 38,9 & 88,5 & 92,4 \\
\hline Черкаська & 63,6 & 72,7 & 87,8 & 86,2 \\
\hline Чернівецька & 66,7 & 77,8 & 93,0 & 84,0 \\
\hline Чернігівська & 43,9 & 54,3 & 86,0 & 94,4 \\
\hline м. Київ & 72,3 & 74,8 & 96,8 & 95,9 \\
\hline Усього & 64,2 & 63,0 & 90,1 & 91,3 \\
\hline
\end{tabular}

тях, а тенденція до збільшення виживання новонароджених із масою тіла при народженні 1000,01499,0 г - за рахунок збільшення його у 15 регіонах.

Ефективність регіоналізації перинатальної допомоги вивчалася і за даними материнських перинатальних і неонатальних втрат, які $€$ основними критеріями якості та рівня організації роботи перинатальних закладів, ефективності впровадження наукових досягнень у практику охорони здоров'я і водночас інтегруючим показником здоров'я жінок репродуктивного віку. За даними моніторингу, в цілому в Україні у 2014 р. зареєстровано 52 (за даними МО3 України - 66), а у 2015 р. - 49 (за даними МО3 України - 60) випадків материнських втрат. Такі розбіжності зумовлені відсутністю чітких критеріїв розподілу материнських втрат, безпосередньо чи опосередковано пов'язаних з акушерськими причинами.

При ефрективному методичному регулюванні організації перинатальної допомоги основна частка материнських втрат повинна концентруватися у ЗПД третинного рівня. Із 49 материнських втрат у 2015 р. у ЗПД І рівня і поза ЗПД померло 19 жінок, на вторинному і третинному рівнях надання пери- натальної допомоги - 6 і 24 жінки відповідно. Позитивним є фракт збільшення індексу концентрації материнських втрат у ЗПД ІІІ рівня до 49,0\% проти $36,5 \%$ у 2014 р. (ВШ 3 95\% ДІ 1,5 (0,6-2,98)). Усі випадки материнських втрат відбулися у ЗПД III рівня у Дніпропетровській. Житомирській, ІваноФранківській, Полтавській, Харківській, Хмельницькій областях, 7 із 8 - в Одеській і 4 із $6-$ у Запорізькій областях. Потребує посилення робота із забезпечення маршрутизації пацієнток із ризиком материнської смертності у Вінницькій, Закарпатській, Миколаївській, Рівненській і Чернівецькій областях, де усі випадки материнських втрат (відповідно 4, 3, 3, 2, 2) відбулися у ЗПД । рівня або поза ЗПД. У цілому рівень материнської смертності за даними МіО РПД становив 12,8 на 100 тис. народжених живими у 2014 р. і 12,6 у 2015 р. при поляризації цього показника у 2015 р. від 0,0 у Херсонській області, менше 10,0 у Волинській, Дніпропетровській, Львівській, Тернопільській, Хмельницькій, Чернівецькій областях і м. Києві до більше 20,0 у Вінницькій $(30,5)$, Запорізькій $(30,2)$, Одеській $(29,2)$, Сумській $(40,8)$, Чернігівській $(21,9)$ областях. 
Одними з основних показників, які рекомендує ВООЗ для оцінки якості надання акушерської i неонатологічної допомоги, є перинатальна і неонатальна смертність.

За даними Держкомстату України, рівень перинатальної смертності за досліджуваний період у цілому мав позитивну тенденцію - 10,1 на 1 тис. народжених живими і мертвими у 2011 р. і 9,1 у 2015 р., ВШ з 95\% ДІ 0,89 (0,86-0,93). Аналогічні дані динаміки перинатальних втрат у ЗПД, підпорядкованих МО3 України, отримані і на підставі розрахунку показника перинатальної смертності за методикою ВОО3 BABIES-MATRICA - 9,8 у 2011 p. i 8,9 у 2015 p. (рис. 3).

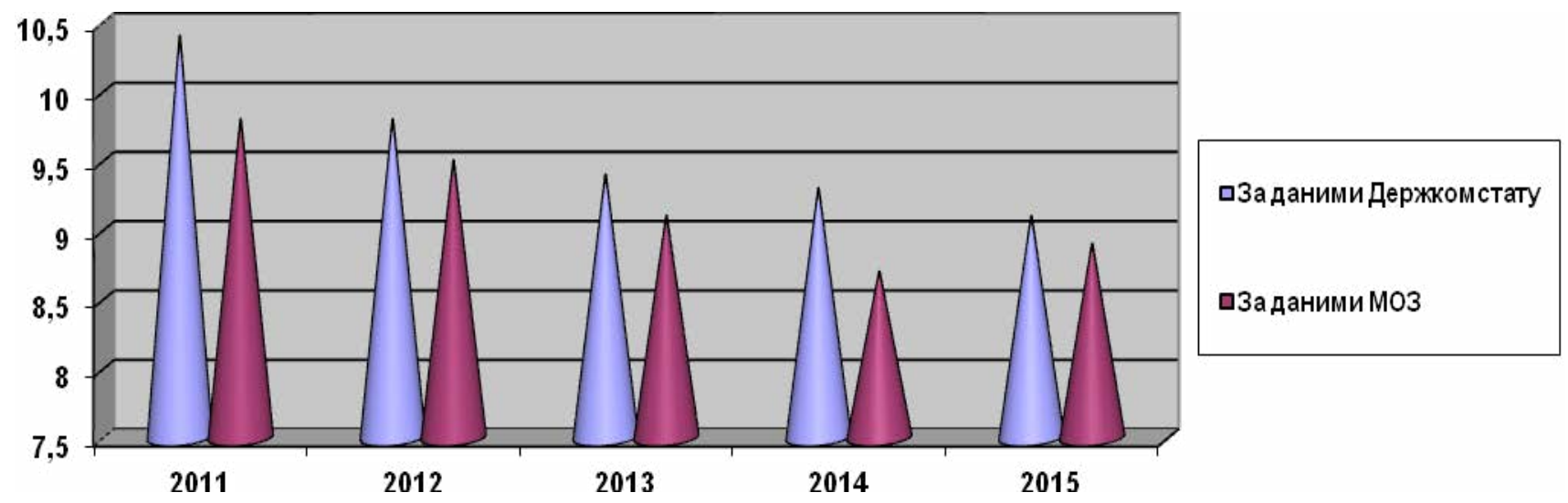

Рис. 3. Порівняльна характеристика динаміки перинатальної смертності в Україні у 2011-2015 рр. на 1000 народжених живими і мертвими (за даними Держкомстату України та галузевої статистики за BABIES-MATRICA)

При загалом сприятливій динаміці перинатальної смертності рівень ії значно перевищує аналогічний показник у середньому по Європі (7,38\%о) та країнах Євросоюзу (6,57\%о). Усе ще високий рівень перинатальної смертності у ЗПД, підпорядкованих МОЗ України, зумовлений високим, значно вищим за пересічний по Україні упродовж останніх років, рівнем перинатальних втрат (вище 10,0 на 1000 народжених живими і мертвими) у Дніпропетровській, Донецькій, Запорізькій, Кіровоградській, Львівській, Харківській і Чернігівській областях. Нижчим від пересічного по Україні упродовж останніх п'яти років, що свідчить про правильність організації перинатальної допомоги, утримувався цей показник у Волинській, Житомирській, ІваноФранківській, Миколаївській, Полтавській, Хмельницькій, Чернівецькій областях та м. Києві.

За даними ВОО3, рівень перинатальної смертності повинен бути обумовлений високим його рівнем серед народжених із дуже малою масою тіла (менше 1500 г), який, в свою чергу, обумовлений високим його рівнем серед народжених із надзвичайно малою масою тіла (500-999 г).

Аналіз пропорційного показника перинатальної смертності (пропорційне співвідношення маси тіла при народженні до загального числа народжених живими і мертвими у всіх вагових категоріях) за даними BABIES-MATRICA засвідчив зменшення перинатальної смертності в Україні за 20092015 рр. за рахунок зниження цього показника у всіх вагових групах немовлят. При цьому рівень пропорційного показника перинатальної смерт- ності обумовлений високим його рівнем у групі новонароджених із масою тіла 1500 г і більше (проміжною і нормальною вагою тіла при народженні), який майже удвічі перевищує рівень пропорційного показника перинатальної смертності серед народжених із низькою масою тіла при народженні (менше 1500 г) (6,21 і 3,59 у 2011 р. та 5,42 і 3,43 у 2015 р. відповідно), що може свідчити як про некоректність реєстрації народження і смертності дітей із дуже низькою масою тіла при народженні, так і про наявність проблем в організації перинатальної допомоги.

Упродовж усіх років перевищення рівня пропорційного показника перинатальної смертності серед народжених 3 масою тіла 1500 г і більше над відповідним рівнем серед народжених з масою тіла менше 1500 г зареєстровано в усіх адміністративних територіях України. У 2015 р. рівень пропорційного показника перинатальної смертності серед народжених 3 масою тіла 1500 г і більше перевищував рівень пропорційного показника перинатальної смертності серед народжених із низькою масою тіла при народженні (менше 1500 г) у Донецькій, Івано-Франківській, Житомирській, Закарпатській, Кіровоградській, Полтавській, Рівненській, Херсонській, Черкаській областях у понад двічі, у Миколаївській області - майже утричі. Лише у Львівській області пропорційний показник перинатальної смертності у ваговій категорії менше 1500 г перевищує аналогічний показник у ваговій категорії 1500 г і більше, а у Дніпропетровській і Харківській і областях ці показники відрізняються несуттєво. 
Некоректність цих даних підтверджується частотою народження живими і мертвими з низькою масою тіла при народженні (рис. 4).

За даними ВОО3, питома вага новонароджених із масою тіла при народженні 1000-1499 г становить від 1\% до 1,5\% серед усіх народжених живими і мертвими, а 3 масою тіла при народженні 500-999 г - від 1\% до 1,5\% відповідно. В Україні у структурі народжених живими і мертвими за масою тіла при народженні діти з масою менше 5001499 г складають дуже низький відсоток упродовж останніх років - 0,93\% у 2011 р. і 1,0\% у 2015 році. У 2015 р. частота народжених живими і мертвими 3 дуже низькою масою тіла при народженні була $\geq 1,0 \%$ лише у Дніпропетровській (1,34\%),
Запорізькій (1,32\%), Львівській (1,3\%), Харківській $(1,25 \%)$, Херсонській $(1,0 \%)$ областях та м. Києві (1,0\%).

Проведений роздільний аналіз динаміки мертвонароджуваності і ранньої неонатальної смертності виявив зміни у співвідношенні цих показників при загальній тенденції до їх зниження. За даними перинатального аудиту за BABIES-MATRICA, у структурі основних складових перинатальної смертності упродовж усіх років спостереження випадки мертвонароджуваності перевищували випадки ранньої неонатальної смертності у 1,6-1,8 разу при високій, вище від орієнтовної (53-55\%), питомій вазі мертвонароджених серед перинатальних втрат упродовж останніх трьох років (61,3-64,4\%) (рис. 5).

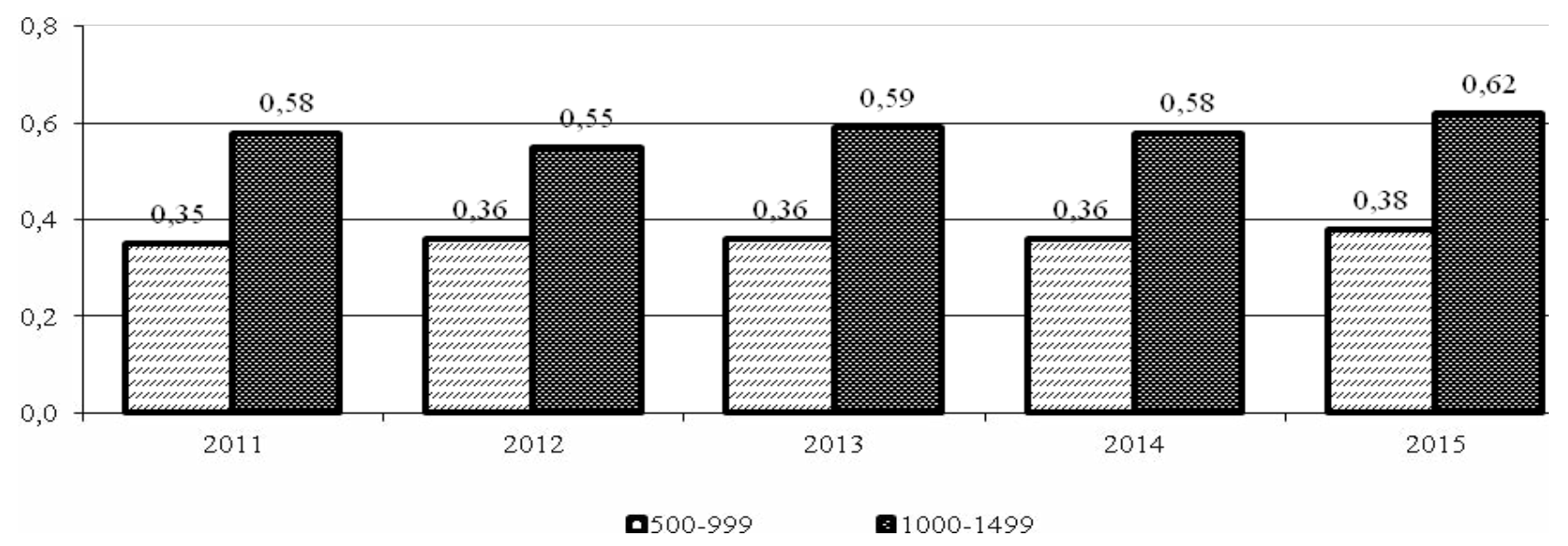

Рuc. 4. Динаміка народження живими і мертвими з низькою масою тіла (менше 1500 г) в Україні у 2011-2015 рр. (на 100 народжених живими і мертвими), \%

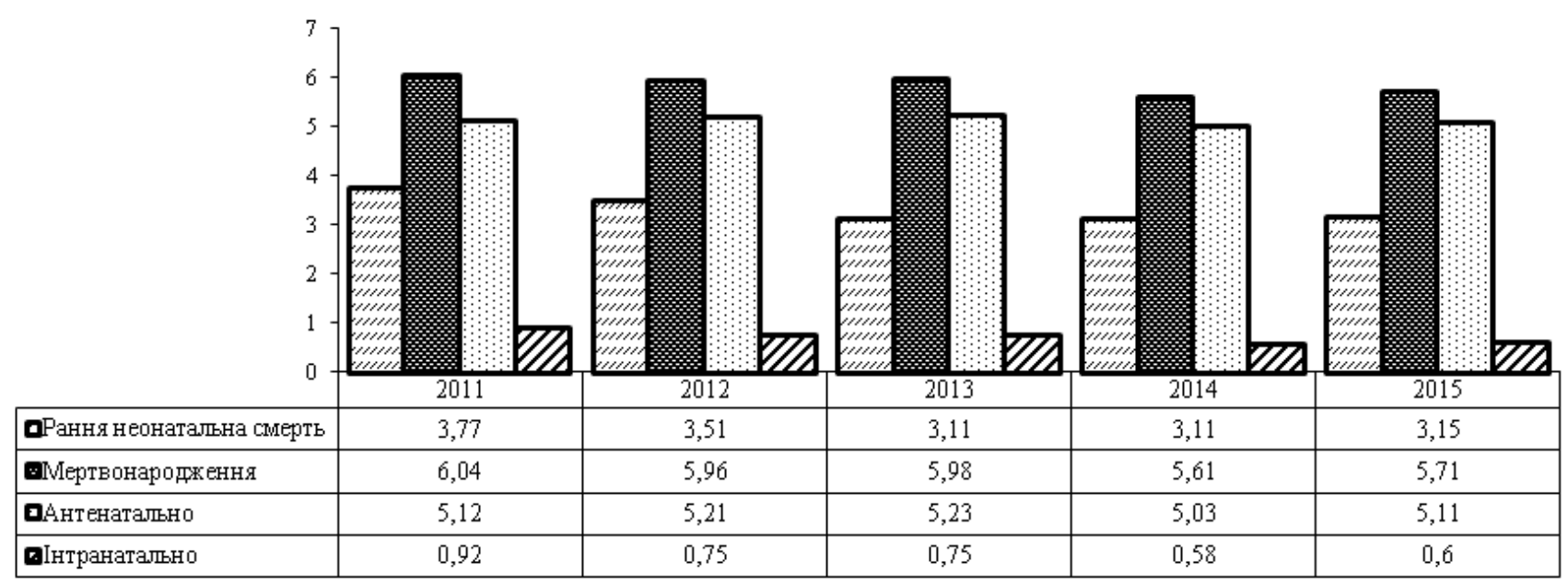

Рис. 5. Динаміка пропорційного показника основних складових перинатальної смертності мертвонароджуваності і ранньої неонатальної смертності в Україні у 2011-2015 рр. (на 1000 народжених живими і мертвими)

Усе ще велика частка мертвонароджуваності у структурі перинатальної смертності засвідчує необхідність подальшого удосконалення медичної допомоги вагітним, що передбачено наказами МО3 України від 15.07.2011 р. №417 «Про орга- нізацію амбулаторної акушерсько-гінекологічної допомоги в Україні» та від 31.10.2011 р. № 726 «Про удосконалення організації надання допомоги матерям та новонародженим в перинатальних центрах». 
Упродовж 2011-2015 рр. пропорційний показник антенатальної загибелі плода залишався на рівні 5,12-5,11 на 1000 народжених живими і мертвими. Проте за зазначений період спостерігається зростання рівня антенатальної загибелі плода при високих, більше 5,0, її показниках - у Запорізькій, Рівненській, Харківській, Херсонській і Чернігівській областях, що потребує вивчення його причин.

Рівень пропорційного показника інтранатальної загибелі плода за цей період знизився з 0,9 на 1000 народжених живими і мертвими у 2011 р. до 0,6 у 2015 р. $з$ позитивною динамікою цього показника в усіх регіонах.

За даними ВОО3, пропорційний показник ранньої неонатальної смертності серед немовлят 3 вагою тіла при народженні більше 1500 г орієнтовно становить біля 1,0 на 1000 народжених живими і мертвими. В Україні його рівень не відповідає міжнародним стандартам і становить 1,7 на 1000 народжених живими і мертвими (рис. 6).

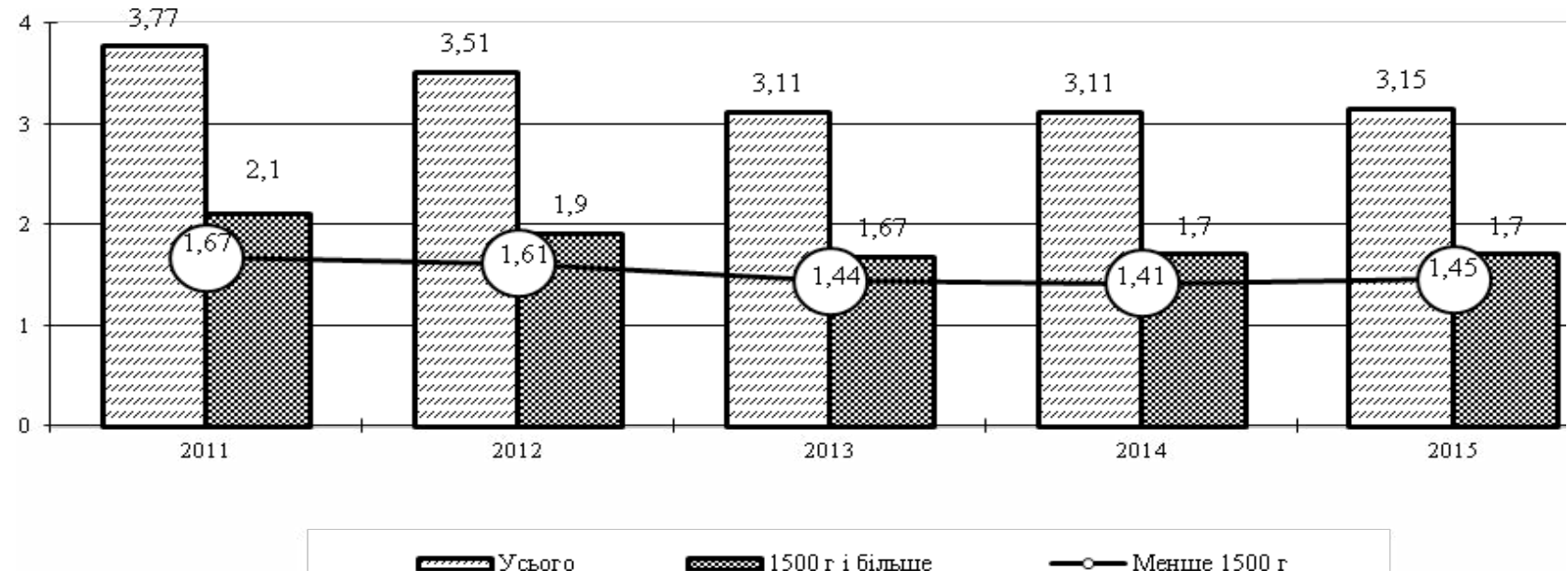

Puc. 6. Динаміка пропорційного показника ранньої неонатальної смертності новонароджених із масою тіла при народженні 1500 г і більше в Україні у 2011-2015 рр. (на 1000 народжених живими і мертвими)

Орієнтовні пропорційні показники ранньої неонатальної смертності новонароджених із масою тіла при народженні 1500 г і більше у 2015 р. зареєстровані лише у Волинській (0,88 на 1000 народжених живими і мертвими), Житомирській $(0,84)$, Київській $(1,03)$ областях, а надвисокі - більше 2,3 - у Донецькій, Луганській, Кіровоградській, Сумській, Тернопільській, і Черкаській областях.

Технологія перинатального аудиту за BABIESMATRICA дозволяє визначити реальний рівень ранньої неонатальної смертності в регіонах, якщо розрахувати його відповідно до критеріїв ВООЗ стосовно структури народжуваності живими і мертвими за ваговими категоріями. Це один із методів оцінити недооблік рівня ранньої неонатальної смертності в Україні і в розрізі територій та, відповідно, підрахувати, якими були б ці показники, якби структура народжених живими і мертвими за віковими категоріями відповідала категоріям ВООЗ з цих питань. Недооблік у ранній неонатальній смертності - це частково не взяті до уваги втрати народжених живими і мертвими, тобто народження, що не зареєстровані, а це один із резервів збільшення кількості дітей, що народилися.

Найбільше заниження рівня ранньої неонатальної смертності за даними BABIES-MATRICA у 2015 р. (у три і більше разів) виявлено у Волин- ській, Житомирській, Івано-Франківській, Миколаївській областях (рис. 7). Менше середнього по Україні розходження між фрактичним і реальним показником ранньої неонатальної смертності у 2015 р. (менш ніж удвічі) відмічалося лише у Дніпропетровській, Запорізькій, Херсонській областях та м. Києві.

Усі виявлені зміни і взаємозв'язки можна інтерпретувати двояко. Враховуючи, що основна доля втрат у перинатальному періоді припадає на мертвонароджуваність, можна припустити, що в Україні досить успішно впроваджуються сучасні технології медичного догляду новонароджених. 3 іншого боку, розрахункові дані реального рівня ранньої неонатальної смертності свідчать про великі резерви зниження і постнатальної складової, а отже слід посилювати зусилля, спрямовані на зниження рівня цієї компоненти.

\section{Висновки}

Ефективність впровадження регіоналізації перинатальної допомоги підтверджена достатніми порівняно $з$ даними ВООЗ у економічно розвинених країнах показниками виживання новонароджених у перші 168 годин життя: з дуже малою масою тіла 81,3\%-81,9\%, у т. ч. 3 масою тіла при народженні 500-999 г - 64,2\%-63,0\%; з масою тіла при народженні 1000-1499 г - 90,1\%-91,3\%. При цьому не підтверджена гіпотеза залежності вижи- 


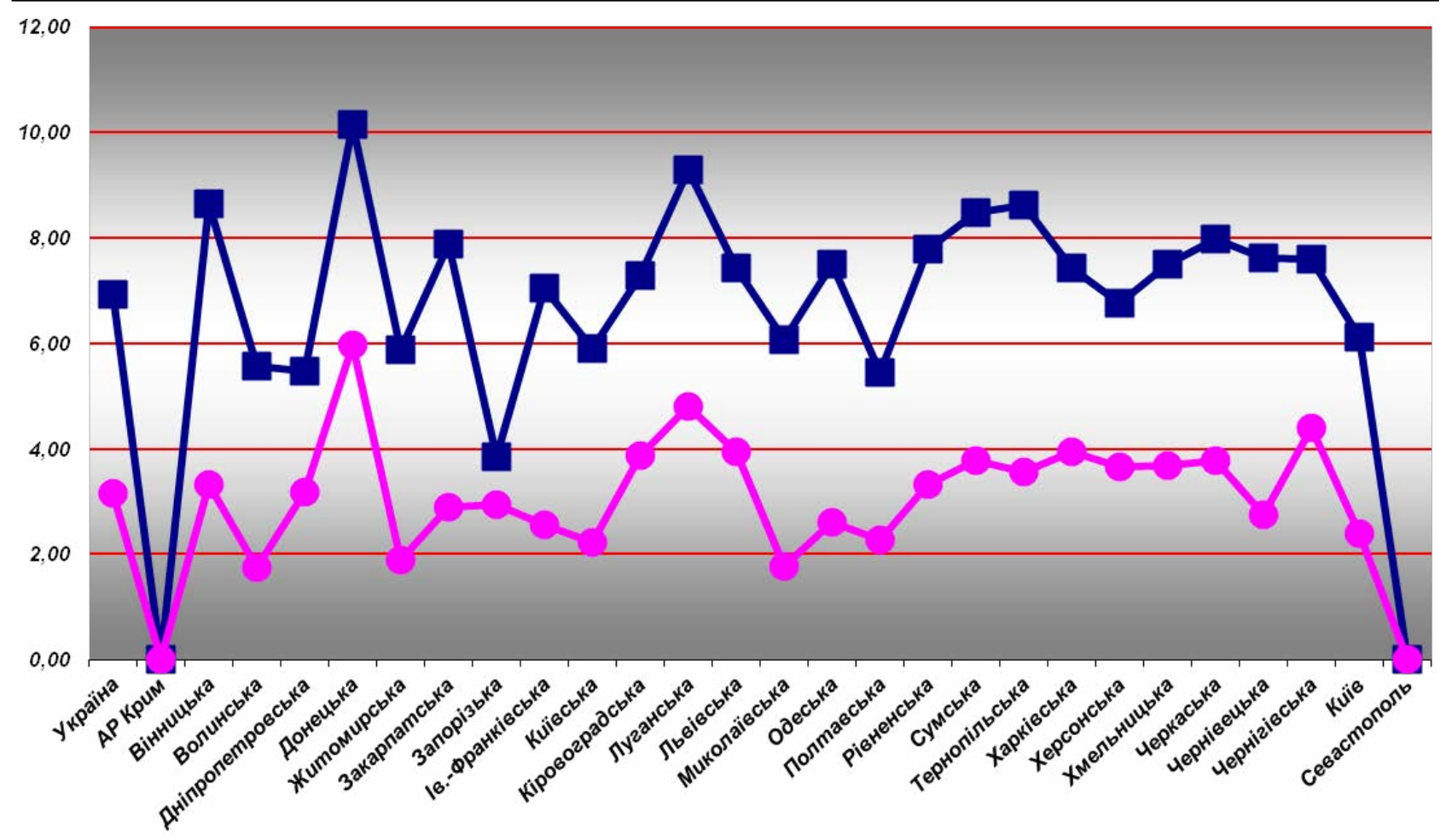

Рuc. 7. Характеристика реального і фактичного рівнів ранньої неонатальної смертності в Україні у 2015 р. у розрізі регіонів (на 1000 народжених живими і мертвими)

вання немовлят із дуже малою масою тіла при народженні від рівня ЗПД (найвищий рівень у ЗПД III рівня і найнижчий у ЗПД І рівня) - за даними МіО РПД рівень виживання немовлят цієї вагової категорії у ЗПД ІІ рівня вищий, ніж у ЗПД ІІІ рівня.

Характерна і позитивна тенденція у ЗПд перинатальної - 8,6 на 1000 народжених живими і мертвими у 2014p. і 8,5 у 2015 р. та неонатальної
- 3,4 на 1000 народжених живими і 3,1 смертності відповідно при відносно низьких показниках материнської смертності (12,6 на 100 тис. народжених живими у 2014 р. і 12,8 у 2015 р.).

Перспективи подальших досліджень пов'язані з вивченням якості життя новонароджених дітей із низькою масою тіла при народженні.

\section{Список літератури}

1. Глобальная стратегия охраны здоровья женщин и детей [Электронный ресурc]. - Режим доступа : http://www.who. int/pmnch/activities/jointactionplan/20100910_gswch_russian.pdf. - Название с экрана.

2. Дети: сокращение смертности : информационный бюллетень № 178. Женева, ВОЗ, 2012 [Электронный ресурс].

- Режим доступа : http://www.who.int/mediacentre/ factsheets/fs178/ru/ index.html. - Название с экрана.

3. Дудіна О. О. Нормативно-правове забезпечення регіоналізації перинатальної допомоги в Україні / О.О.Дудіна, У. В. Волошина // Економіка і право охорони здоров'я. - 2015. - № 1 (1). - С. 64-69.

4. Дудіна О. О. Оцінка ефективності впровадження медико-організаційних технологій клінічних протоколів / О. О. Дудіна, Р. О. Моісеєнко, Г. І. Лізунова // Україна. Здоров'я нації. - 2012. - № 1 (21). - С. 61-64.

5. Дудіна О. О. Покращення умов для виживання і підвищення якості життя жінок / О. О. Дудіна // Міжгалузева комплексна програма «Здоров'я нації 2002-2012». - Київ, 2012. - С. 33-47.

6. Європейська база даних «Здоров'я для всіх» [Електронний ресурс]. - Режим доступу : http://www.euro.who.int/ hfadb. - Назва з екрану.

7. Мировая статистика здравоохранения. 2012 год. - Женева : ВО3, 2013. - 176 с.

\section{ХАРАКТЕРИСТИКА ВИЖИВАНИЯ НОВОРОЖДЕННЫХ С НИЗКОЙ МАССОЙ ТЕЛА ПРИ РОЖДЕНИИ}

\section{Е.А. Дудина ${ }^{1}$, Ю.Ю. Габорец ${ }^{1}$ Г.А. Дзюба 2}

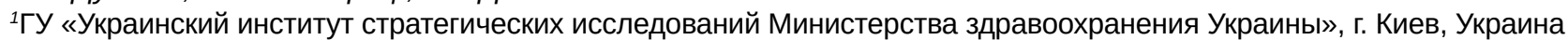
${ }^{2}$ Национальная медицинская академия последипломного образования имени П.Л. Шупика, г. Киев, Украина

Цель: изучить и проанализировать показатели выживания новорожденных с низкой массой тела при рождении в условиях внедрения регионализации перинатальной помощи в Украине. 
Материалы и методы. В ходе исследования использованы статистический и библиосемантический методы. Материалами исследования стали данные Госкомстата Украины и перинатального аудита за 20112015 годы.

Результаты. Показатели выживания новорожденных с очень низкой массой тела в первые 168 часов жизни составили 81,3\%-81,9\%, В т. ч. с массой тела при рождении 500-999 г -64,2\%-63,0\%, с массой тела при рождении 1000-1499 г - 90,1\%-91,3\%. Установлена положительная тенденция относительно перинатальной смертности - 8,6 на 1000 рожденных живыми и мертвыми в 2014 г. и 8,5 в 2015 г. и неонатальной - 3,4 и 3,1 на 1000 рожденных живыми соответственно.

Выводы. Показана эффективность внедрения регионализации перинатальной помощи в стране.

КЛЮЧЕВЫЕ СЛОВА: новорожденные с низкой массой тела при рождении, выживание, перинатальная помощь, регионализация.

\section{CHARACTERISTIC OF SURVIVAL OF NEWBORNS WITH LOW WEIGHT AT BIRTH}

\section{O.O. Dudina', Yu.Yu. Gaborets ${ }^{1}$, G.A. Dziuba ${ }^{2}$}

${ }^{1} \mathrm{PE}$ «Ukrainian Institute of Strategic Research MHC of Ukraine», Kyiv, Ukraine

${ }^{2}$ Shupyk National Medical Academy, Kyiv, Ukraine

Goal of study: to consider and analyze the indices of survival of newborns with low weight at birth in the conditions of implementation of perinatal care regionalization in Ukraine.

Materials and methods. Statistical and bibliosemantic methods were used in the course of research. The data of State Committee of Statistics and perinatal audit for the years 2011-2015 were taken as material for study.

Results. The indices of survival of the newborns with extremely low weight in the first 168 hours of life equal to $81.3 \%-81.9 \%$, including the babies with the weight 500-999 grams at birth (64.2\%-63.0\%) and newborns with the weight $1000-1499$ grams at birth (90.1\%-91.3\%). Positive trend of perinatal mortality - 8.6 per 1000 of births dead and alive in 2014 and 8.5 in 2015, and neonatal mortality 3.4 per 1000 of births dead and alive and 3.1 respectively is set.

Conclusions. The effectiveness of the implementation of perinatal care regionalization in the country is demonstrated in the article.

KEY WORDS: newborns with low weight at birth, survival, perinatal care, regionalization.

Рукопис надійшов до редакції 21.10.2016 р.

\section{Відомості про авторів:}

Дудіна Олена Олександрівна - к.мед.н., с.н.с., завідувач відділення охорони здоров'я матері і дитини ДУ «Український інститут стратегічних досліджень МОЗ України»; тел. служб.:+38(044) 576-41-16.

Габорець Юрій Юрійович - пошукувач ДУ «Український інститут стратегічних досліджень МОЗ України»; тел. служб.: +38(044) 576-41-19.

Дзюба Галина Анатоліївна - к.мед.н., доц. кафедри акушерства, гінекології та перинатології Національної медичної академії післядипломної освіти імені П.Л. Шупика. 